\title{
FRUIT AND SEED BIOMETRY AND SEEDLING MORPHOLOGY OF Parkia discolor (Spruce ex Benth.) ${ }^{1}$
}

\author{
Sammy Aquino Pereira ${ }^{2 *}$ and Sidney Alberto do Nascimento Ferreira ${ }^{3}$
}

\footnotetext{
${ }^{1}$ Received on 01.09.2014 accepted for publication on 28.11.2016.

${ }^{2}$ Instituto Nacional de Pesquisas da Amazônia, Programa de Pós-Graduação em Ciências de Florestas Tropicais, Manaus, AM - Brasil. E-mail: <sammy.aquino@gmail.com>.

${ }^{3}$ Instituto Nacional de Pesquisas da Amazônia, Manaus, AM - Brasil. E-mail:<sanf@inpa.gov.br>.

*Corresponding author.
}

\begin{abstract}
Parkia discolor (Spruce ex Benth.) is a species of floodplain forest permanently flooded, mainly used in folk medicine and with economic potential. The purpose of this study was to estimate the biometric characteristics of fruits and seeds of Parkia discolor and describe the morphology and development of its seedlings and young plants. On average, fruits have shown the following dimensions: $18.45 \mathrm{~cm}$ long with pedicel, $13.25 \mathrm{~cm}$ long without pedicel, $4.4 \mathrm{~cm}$ wide and $0.66 \mathrm{~cm}$ thick mass of $11.91 \mathrm{~g}$. The seeds have shown 1.73 $\mathrm{cm}$ long, $0.68 \mathrm{~cm}$ wide and $0.39 \mathrm{~cm}$ thick mass of $0.38 \mathrm{~g}$. A thousand seeds mass was estimated to be 361.15 $\mathrm{g}$ and the number of seeds per kilogram was 2769. The fruits and seeds of these species are preyed by insects of the families Scolytidae, Nitidulidae, Cerambycidae and Bruchidae. Germination is epigeal - phanerocotylar; the seedling presents hypocotyl herbaceous, sessile cotyledons, based split, eophyll compound, paripinnatus with 1-3 pairs of leaflets, most 2 pairs, with the insertion of a spherical gland leaflets, bright green. The young plant has a woody base with 5 eophylls, alternate and presents between 21-26 pairs of foliolums. The use of plastic bags of $900 \mathrm{~cm}^{3}$ was more proper than using a styrofoam tray with "cell" of $125 \mathrm{~cm}^{3}$ for the development of the plants during the period of three months.
\end{abstract}

Keywords: Biometric characteristics; Morphological studies; Fabaceae.

\section{BIOMETRIA DO FRUTO E DA SEMENTE E MORFOLOGIA DA PLÂNTULA DE Parkia discolor (Spruce ex Benth.)}

\begin{abstract}
RESUMO-Parkia discolor (Spruce ex Benth.) é uma espécie de floresta inundável de igapó, utilizada principalmente na medicina popular e com potencial econômico. Este trabalho teve como objetivo estimar as características biométricas de frutos e das sementes e descrever a morfologia e o desenvolvimento da plântula e da planta jovem de Parkia discolor. Em média, os frutos apresentaram as seguintes dimensões: 18,45 cm de comprimento com pedicelo, 13,25 cm de comprimento sem pedicelo, 4, $4 \mathrm{~cm}$ de largura, 0,66 cm de espessura e massa de 11,91 g. As sementes apresentaram $1,73 \mathrm{~cm}$ de comprimento, $0,68 \mathrm{~cm}$ de largura, $0,39 \mathrm{~cm}$ de espessura e massa de 0,38 g. A massa de mil sementes foi estimada em 361,15 g e número de sementes por quilo de 2769. Frutos e sementes da espécie são predados por insetos das famílias Scolytidae, Nitidulidae, Cerambycidae e Bruchidae. A germinação é epígea-fanerocotiledonar; a plântula apresenta hipocótilo herbáceo, cotilédones sésseis, com base fendida, eofilo composto, paripinado, apresentando de 1 a 3 pares de foliolos, maioria 2 pares, apresentando na inserção dos foliolos uma glândula esférica, verde-clara. A planta jovem apresenta base lenhosa, com 5 eofilos, alternos, os quais apresentam entre 21-26 pares de foliolos. O uso de sacos de plástico de $900 \mathrm{~cm}^{3}$ foi mais adequado que a bandeja de isopor, com "célula" de $125 \mathrm{~cm}^{3}$, para o desenvolvimento da muda durante o período de três meses.
\end{abstract}

Palavras-chave: Características biométricas; Estudos morfológicos; Fabaceae. 


\section{INTRODUCTION}

The Parkia genus belongs to Fabaceae family and it presents 17 species in Brazil with higher ocurrence in Amazonia, Atlantic Forest and the Cerrado (Iganci, 2015). Among the species which represent that genus Parkia discolor (Spruce ex Benth.) stands out, commonly known as visgueiro-of-igapó, arapari, piradabi, araratucupi and faveira. It is a kind of small tree or a medium height one with a few ramification, often irregular crown, open, with twisted and long twigs (Hopkins, 1986). Developed in igapó flooded forest, mainly on the banks of Negro river with also ocurrence in isolated populations in other parts of Amazonia, with uses at folk medicine (Hopkins, 1986), with ecologic (Cavada et al., 2000) and economic (Souza and Silva, 2003) potentials.

Despite its uses and economic potential little is found in literature about morphological characteristics of its reproductive organs, propagules, germination and seedlings development being this knowledge necessary for management, propagation and ecological studies with regard to domestication of species.

A great quantity of taxonomic and phylogenetic characteristics is given for seeds (varying in size, shape, color and superficial aspect of testa), fruits and seedlings which allow to identify and detect the genetic variability in populations of the same specie; as well as support the morpho-anatomic studies or in ampliation of knowledge about determined specie or vegetable group (Santos et al., 2014; Silva et al., 2014a).

In this context works about seed and seedlings morphology are used to studies of seed identification and plants in young stage which are presented during a succession of a specie, in related studies with the development of the vegetation (Baos et al., 2014; Rodrigues et al., 2014).

For the purpose of a specie's domestication, the planting of forests depend, among other factors, of the seedlings quality produced. Those, despite having greater capacity of resisting to diverse conditions found in the field, they should grow as fast as possible to compete with spontaneous vegetation and diminish possible damages caused by forest pests. The amount of seedlings depend, among other factors again, on the type of vessel used since they allow the suitable formation of root system and contribute to the maximum survival and initial growth in the field (Carneiro, 1995; Gomes et al., 2016; Gonzaga et al., 2016).

Revista Árvore. 2017;41(2):e410206
With the aim of enlarging the knowledge of the native flora from igapó areas and contribute in the recognition of the specie in floristic inventories, identification in the seed bank and in its management. This work has the aim to estimate biometric characteristics of fruits and seeds and describe the morphology and also the development of seedlings and the young plant of Parkia discolor (Spruce ex Benth.).

\section{MATERIALAND METHODS}

The fruits and seeds were collected in October 2005 , at the end of fruiting period, coinciding with the start of ebb, in the Sustainable Development Reserve of Tupé, located at $03^{\circ} 02^{\prime} 51^{\prime \prime} \mathrm{S}, 60^{\circ} 15^{\prime} 21^{\prime \prime} \mathrm{W}$, to an altitude of $20 \mathrm{~m}$ a.n.m.; on the left bank of Negro River, to the West of Manaus, approximately $25 \mathrm{~km}$ straight line of the center of the city. The evaluations and the laboratory tests were conducted at Laboratory of Seeds and at Seedling Nursery of Coordination Agronomic Sciences Research, of the National Institute for Amazonian Research (INPA), in Manaus (AM).

To estimate the dimensions of fruits were used 100 units, obtained at random, from a batch which is characterized as a mixture of 13 individuals. The variables of fruits were measured: length of fruit, including pedicel (cm); length of fruit, without considering pedicel $(\mathrm{cm})$; width and thickness $(\mathrm{cm})$; mass $(\mathrm{g})$; and number of seeds for pod.

Those same fruits, after the elimination of gum, were reserved randomly, 100 seeds which were measured length, distance from top to base $(\mathrm{cm})$; width and thickness, assessed in the middle line of seeds $(\mathrm{cm})$; and mass (g). To those measures, a metric ruler was used, a digital caliper and also an accuracy electronic scale were. With the values taken, the arithmetic mean, standard deviation and maximum and minimum values were calculated to each variable. By using eight subsamples of 100 seeds, it was estimated the number of seeds per kilogram and the mass of 1000 seeds, as shown in Brasil (2009).

As a contribution to the knowledge of types of plagues which can affect species of this genus, it was used a batch from biometry for measurement of predation of fruit and seeds by means of count the number of holes (signs of predation) for pod and number of seeds predated. The insects collected were identified for specialists, at Coordination of Entomology Research of INPA. 
For the production of seedlings it was installed an experiment in October 2006 to test two types of recipients. For this purpose, parallel to monitoring the development of seedling and the young plant, were used as recipients: 100 black plastic bags of $15 \times 16$ $\mathrm{cm}\left(900 \mathrm{~cm}^{3}\right.$ estimated volume) and 100 "cells" (compartments) of styrofoam plantagil tray (shaped as an inverted pyramid with 4,7 $\mathrm{cm} \mathrm{X} \mathrm{4,7} \mathrm{cm}$ X 11,3 $\mathrm{cm}$; with estimated volume of $125 \mathrm{~cm}^{3}$ ), which were filled with commercial substrate called "composted earth" ( $50 \%$ earth, $30 \%$ of organic compound, more $20 \%$ earthworm compost, v:v:v). From the non-predated seeds batch were taken two seeds for each plastic bag, while in each compartment of the tray it was taken only one. The recipients were kept in covered nursery with shade net of $50 \%$. To accelerate the germination, or emergence, it was carried out the clipping at the distal portion of the seed, the opposite side of radicle protrusion, following the procedure adopted by Pereira e Ferreira (2010).

The period of observation was three months with monitoring of seedling and young plant every three days, irrigation was manual and always necessary. In plastic bags, after the emergence of seedling, thinning was undertaken, leaving a seedling per recipient; related to the styrofoam tray, a great number of "cell" has been cultivated so that, after the emergence, laid 100 seedlings in development.

The stages of seedling considered were since the protrusion of primary root, noticed by "fracturation of substrate", up to the $1^{\text {st }}$ eophyll completely expanded; at the young plant, was from the emergence of the $2^{\text {nd }}$ eophyll up to the 5 th expanded eophyll. The described and illustrated vegetative elements were root, hypocotyl, cotyledon, epycotyl, eophyll $\left(1^{\text {st }}, 2^{\text {nd }}, 3^{\text {rd }}, 4^{\text {th }}\right.$ and $5^{\text {th }}$ order) and apical bud. The descriptions of seedlings and young plants were made considering mainly the most representative stages of them, based on the works of Damião-Filho (1993) and Ribeiro et al. (1999). The illustrations of the morphologic traits were hand made, with naked eye and with the help of stereomicroscope Olympus 4x.

At the end, after three months of observations, there was the characterization concerning to the seedling production, the variables were: total height (distance in centimeters between the colon and the base of apical bud), dry matter of leaves, stem and roots (mass in grams of the plant parts after oven-drying, with forced air circulation at $65^{\circ} \mathrm{C}$, until the reach of constant weight), rate part aerial/radicular system (relation between the sum of the stem and leaves dry matter with the dry matter of the root) and rate of leaf mass (relation between leaves dry matter with total dry matter) of young plants. In this case, the experimental design was entirely at random, with two treatments (plastic bags and styrofoam tray) and three repetitions, each one constituted by the mean of 10 individuals. After the analysis of variance, the means were compared by Tukey test at the level of $5 \%$ of probability.

\section{RESULTS}

The fruits of $P$. discolor presented on average length with pedicel of $18,45 \mathrm{~cm}$ and without pedicel of $13,25 \mathrm{~cm}$; width of $4,40 \mathrm{~cm}$; thickness of $0,66 \mathrm{~cm}$; mass of 11,91 $\mathrm{g}$ and 12,93 seeds for pod (Table 1). The seeds of $P$. discolor presented on average the following dimensions: length of $1,73 \mathrm{~cm}$; width of $0,68 \mathrm{~cm}$; thickness of $0,39 \mathrm{~cm}$ and mass of $0,38 \mathrm{~g}$ (Table 1 ). With water content of $13 \%$, the mass of 1000 seeds was estimated in $361,15 \mathrm{~g}$ and the number of seeds per kilogram was 2769 units.

In fruit and seeds studied batches were observed circular holes caused by insects. On an average, each fruit was found with a hole and three predated seeds (Table 1). Among the insects, based on Borror and De Long (1969), were identified individuals from Coleoptera order, from four families: Scolytidae, Nitidulidae, Cerambycidae and Bruchidae.

The germination is epigeous phanerocotyledonary and it started, on average, on the 6th day after sowing (Table 2), when protrusion of the primary root took place, observed by splitting on soil and concomitant development of hypocotyl, breaking the soil and rising it up to the surface (Figure 1a). The hypocotyl presents initially herbaceous, curved, up to become straight, cylinder, with velvety and abundant trichomes, light green color in colon, and reddish along the hypocotyl (Figure 1b).

The cotyledons were sessile, pearly with purple stains on both, oblonge, rounded apex, intact edge, opposing, isophyilos, glabrons, with slotted base (Figure 1c). From the 8 th day, the cotyledons open and start the formation of epycotil; this is cylindrical, herbaceous, with initial light green color and afterwards reddish, with trichomes in abudance, simple and short, velvet (Figure 1d). On

Revista Árvore. 2017;41(2):e410206

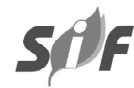


Table 1 - Biometry of fruits and seeds of Parkia discolor harvested in the Sustainable Development Reserve Tupé, in Manaus (AM).

Tabela 1 - Biometria de frutos e sementes de Parkia discolor colhidos na Reserva de Desenvolvimento Sustentável do Tupé, em Manaus (AM).

\begin{tabular}{|c|c|c|c|}
\hline Variables & Means (+/- DP) & Maximum & Minimum \\
\hline \multicolumn{4}{|l|}{ Fruits } \\
\hline Width $(\mathrm{cm})$ & $4,40(0,53)$ & 5,76 & 3,08 \\
\hline Tickness $(\mathrm{cm})$ & $0,66(0,10)$ & 0,98 & 0,46 \\
\hline Length w/pedicel (cm) & $18,45(3,41)$ & 27,00 & 12,00 \\
\hline Length w/o pedicel $(\mathrm{cm})$ & $13,25(2,56)$ & 19,50 & 9,00 \\
\hline $\operatorname{Mass}(\mathrm{g})$ & $11,91 \quad(3,46)$ & 20,40 & 4,51 \\
\hline Number of seeds per fruit & $12,93(2,75)$ & 19,00 & 6,00 \\
\hline Number of holes per fruit & $1,12(1,49)$ & 8,00 & 0 \\
\hline $\mathrm{N}$ of predated seeds /fruit & $3,24(3,92)$ & 15,00 & 0 \\
\hline \multicolumn{4}{|l|}{ Seeds } \\
\hline Width $(\mathrm{cm})$ & $0,68(0,08)$ & 0,92 & 0,52 \\
\hline Thickness (cm) & $0,39(0,06)$ & 0,55 & 0,28 \\
\hline Length $(\mathrm{cm})$ & $1,73(0,16)$ & 2,09 & 1,34 \\
\hline Mass (g) & $0,38(0,08)$ & 0,88 & 0,19 \\
\hline
\end{tabular}

Table 2 - Mean Time (TM) for the seedling and young plant Parkia discolor achieves the different stages of development and the same height when the main stages were achieved, under cultivation in recipients, plastic bags and styrofoam plantagil tray. ( $\mathrm{SD}=+/$ - standard deviation).

Tabela 2 - Tempo médio (TM) para a plântula e planta jovem de Parkia discolor alcançar os diferentes estádios de desenvolvimento e altura das mesmas quando os principais estádios foram atingidos, sob cultivo nos recipientes saco de plástico e bandeja tipo plantágil. ( $D P=+/$ - desvio padrão).

\begin{tabular}{|c|c|c|c|c|}
\hline \multirow[t]{2}{*}{ Development } & \multicolumn{2}{|c|}{ Plastic bags $\left(900 \mathrm{~cm}^{3}\right)$} & \multicolumn{2}{|c|}{ Plantagil tray(“cell", $\left.125 \mathrm{~cm}^{3}\right)$} \\
\hline & TM (DP) (days) & Height (DP) (cm) & $\overline{\mathrm{TM}}(\mathrm{DP})$ (days) & Height (DP) $(\mathrm{cm})$ \\
\hline Protrusion of primary root & $6,2(2,3)$ & - & $5,6(1,2)$ & - \\
\hline Developed Hipocotyl & $6,8(2,0)$ & - & $7,4(1,1)$ & - \\
\hline Emergence of 1 st eophyll & $8,7(2,8)$ & - & $8,1(2,8)$ & - \\
\hline 1st eophyl expanded & $11,7(2,4)$ & $12,7(2,0)$ & $13,6(1,2)$ & $11,8(2,2)$ \\
\hline Fall of cotyledons & $14,8(0,9)$ & - & $14,6(0,6)$ & - \\
\hline Emergence of 2 nd eophyll & $17,9(3,3)$ & - & $17,3(5,0)$ & - \\
\hline 2nd eophyll expanded & $30,7(3,8)$ & $17,3(2,3)$ & $31,0(6,4)$ & $16,5(2,5)$ \\
\hline Emergence of 3rd eophyll & $34,2(4,6)$ & - & $33,9(3,9)$ & - \\
\hline 3rd eophyll expanded & $53,6(3,5)$ & $22,2(2,6)$ & $53,9(4,0)$ & $21,1(3,6)$ \\
\hline Emergence of 4th eophyll & $61,3(3,1)$ & - & $60,1(2,6)$ & - \\
\hline 4th eophyll expanded & $75,0(4,3)$ & $26,7(3,4)$ & $78,3(6,4)$ & $25,3(3,7)$ \\
\hline Emergence of 5 th eophyll & $81,1(6,7)$ & - & - & - \\
\hline 5th eophyll expanded & $88,4(4,5)$ & $32,1(3,3)$ & - & - \\
\hline
\end{tabular}

the 12th day, the 1th eophyll was expanded, compound, paripinnate, subsessile, presenting from 1 to 3 pairs of foliolums, although the majority presents 2 pairs of foliolums in each side.

It present pulvinus with short trichomes in abundance, reddish in color. Short rachis, corrugated, herbceous, from green and red, with velvety trichomes. In the insertion of foliolums it was observed a spherical gland, light green, glabron. Short pulvinus, intumesced, reddish, covered by simple and short trichomes. Petiolule, short, cylindric, with velvety trichomes. Sessile leaflets, oblonge, rounded apex, irregular and oblique base, intact border, leaf blade coriacea, green on the adaxial face and green with red stains on the abaxial face, glabron on both faces, with main nervate as trinervate prominent or evident on adaxial face and prominula on abaxial face; secondary venations with brochidodromus venation.

The young plant presents straight stem, of woody base, cylindric, brown on the base and light green as long as it goes to the apex. The cotyledons fall, on 


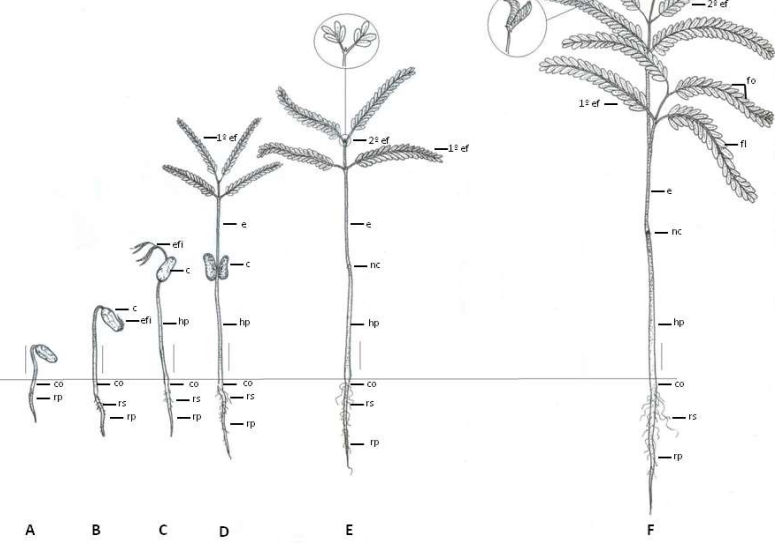

Figure 1 -A-D. Aspect of seedling; E-F. Aspects of the young plant Parkia discolor. (rp - primary root; rs lateral root; co - colon; hp - hypocotyl; nc node cotyledonary; c - cotyledon; efi - eophyll immature; e - epicotyl; 1 oef - 1 st eophyll; fo - leaflet; fl - foliolum, 2nd f - 2nd eophyll; 3 ${ }^{\circ} \mathrm{f}$ - $3 \mathrm{rd}$ eophyll. Scale: $\left.1 \mathrm{~cm}\right)$.

Figura 1-A-D. Aspecto da plântula; E-F. Aspectos da planta jovem de Parkia discolor. ( $r p$ - raiz primária; rs-raiz lateral; co-coleto; $h p$ - hipocótilo; $n c-n o ́$ cotiledonar; $c$-cotilédone; efi-eofilo imaturo; e-epicótilo; $1^{\circ}$ ef- $1^{\circ}$ eofilo; fo-foliolo; $f l$-foliólulo; $2^{\circ}$ ef- $2^{\circ}$ eofilo; $3^{\circ}$ ef- $3^{\circ}$ eofilo. BARRA: $1 \mathrm{~cm}$ ).

average, with 14 days after sowing, leaving an evident scar (Figure 1e). To the direction of apex, the epycotile turns to herbaceous, hairy, the trichomes are simple, short, withish, recovering the whole surface. The 1st eophyll is simple, paripinnate, the oldest foliolums are dark green, while the young ones are light green on both sides, presenting 14-19 pairs of foliolums; and the eophylls of $2^{\text {nd }}, 3^{\text {rd }}, 4^{\text {th }}$ and $5^{\text {th }}$ order present between
21-26 pairs of foliolums (Figure 1f). In the insertion of foliolums it was observed a spherical gland, light green. In the inferior insertion of each eophyll there is a vegetative gem greenish yellow and densely hairy, where there will be the formation of a new leaf. Its development starts with the final expansion of the previous leaf.

It was observed a significant difference to the height, dry matter of the root and rate aerial/radicular system, depending on the recipient where the plant has developed. The greatest rates were found when development took place in plastic bags due to major volume of substrate and nutrients to its development (Table 3).

\section{DISCUSSION}

Coutinho and Struffaldi (1971) observed, concerning to $P$. discolor seeds, length between 1-1,5 cm, different from the results achieved on the present work which were 1,34-2,09 cm. Similar outcomes were achieved by Hopkins (1986) and Moreira and Moreira (1996). The samples used for the experiments of the authors, including this research, were collected in periodically flooded areas which allowed to infer that the variables of mass and dimension of fruits and seeds of $P$. discolor observed in these researches can be attributed to interactions with the factors in each locality, where the matrices were and, or, due to genetic variation among them.

Some researches with other species of Parkia allow to observe some differences of size among fruits, quantity and size of seeds which are characteristics that can easily be used to differ species of this genus with the help of morphology. Camara et al. (2008) observed for Parkia pendula fruits means of length of $20 \mathrm{~mm}, 20$ seeds per fruit, and means of seeds length of $10,1 \mathrm{~mm}$. Rocha et al (2014) observed for Parkia multijuga seeds with means of $46,37 \mathrm{~mm}$ of length.

Table 3 - Height, dry matter (leaves, stem and root), the ratio shoot / root ratio and leaf mass related to the young plant (seedling) Parkia discolor after three months of development in plastic bag and type plantagil tray under shading nursery with $50 \%$ in Manaus (AM).

Tabela 3 - Altura, matéria seca (folha, caule e raiz), razão parte aérea/sistema radicular e razão massa foliar referentes à planta jovem (muda) de Parkia discolor após três meses de desenvolvimento em saco de plástico e em bandeja do tipo plantágil, sob viveiro com sombreamento de 50\%, em Manaus (AM).

\begin{tabular}{|c|c|c|c|c|c|c|}
\hline \multirow[t]{2}{*}{ Recipient } & \multirow[t]{2}{*}{ Height $(\mathrm{cm})$} & \multicolumn{3}{|c|}{ Dry matter $(\mathrm{g})$} & \multirow{2}{*}{$\begin{array}{c}\text { Ratio part } \\
\text { aerial/radicular } \\
\text { system }\end{array}$} & \multirow{2}{*}{$\begin{array}{c}\text { Ratio } \\
\text { foliar mass }\end{array}$} \\
\hline & & leaves & stem & $\operatorname{root}$ & & \\
\hline Styrofoam tray (“cell”, $\left.125 \mathrm{~cm}^{3}\right)$ & $25,19 \mathrm{~b}$ & 0,22 & $0,56 \mathrm{~b}$ & 0,28 & $2,8 \mathrm{~b}$ & 0,21 \\
\hline Plastic $\operatorname{Bag}\left(900 \mathrm{~cm}^{3}\right)$ & 28,16 a & 0,26 & $0,78 \mathrm{a}$ & 0,23 & $4,4 \mathrm{a}$ & 0,21 \\
\hline C.V. $(\%)$ & 4,63 & 12,82 & 13,90 & 14,23 & 5,98 & 4,76 \\
\hline
\end{tabular}

Note: Means followed by different letters, in column, differ significantly with each other by Tukey test to the level of $5 \%$ of probability. 
Insects from Bruchidae Family were the most importante in terms of fruit and seed attack in species of Parkia genus (Hopkins, 1983; Hopkins and Hopkins, 1983). Teixeira (2005) observed in Parkia multijuga Benth. that in the period which pods/seeds reach the maturation, the insect also reach the adult phase, passing to emerge from pods/seeds and drilling the tegument of hosts. The same author also assures that part of perforated seeds have its embryo intact and it presents germination potential, that is to say, when they came to get perforated on the forest floor, they are the most promptly suitable to germinate. Suggesting studies related to biological interaction and effect on the species germination of genus.

The characteristics of seeds, like size as well as like morphofunctional nature of cotyledons, which can be of reserve or photosynthetic, are the two main characteristics present at the start of cycle of life of plants; so as the characteristics of the germination phase up to the complete development of young plant, as the shape of blade, from the edge of the apex, position of eophylls, presence or absence of latex or resin, relation length/width of cotyledons, size and number of pines, winged petiole or not which allow to characterize families, genera and even species which are subsidies that can facilitate a more precise identification of species, especially those present in the forest ecosystems (Gurgel et al., 2012).

Moreira e Moreira (1996) describe initial morphology of $P$. discolor like epigous, what is confirms the observation made on this study. Publications regarding to a seedling morphology of species from Parkia genus are scarce (Hopkins, 1986; Santana et al., 2015), in general they focus on overcoming dormancy of seeds (Pereira and Ferreira, 2010; Melo et al., 2011; Silva et al., 2014b). IbarraManríquiz et al. (2001) describe a epigous type of germination frequent in Fabaceae, nevertheless it was observed by Melo (2011) that germination in P. multijuga Benth. is hypogeal criptocotiledonar, semi- hipogeal fanerocotiledonar in P. velutina Benoist and epigous fanerocotiledonar in P. panurensis Benth. ex H.C. Hopkins. The coloration of cotyledons can help in the distinction of species, $P$. panurensis present covered with stains red ferruginea, more evident at the edges, while $P$. discolor and $P$. velutina present purple stains on both sides.

On the base of foliolums it was observed a spherical gland, in which Melo (2011) characterizes like nectariferous gland and it was also observed in the three species $P$. multijuga, $P$. velutina e $P$. panurensis. Hopkins (1986) reports that $P$. multijuga presented 22 to 23 pairs of leaflets per pine, Melo (2011) observed 24 to 26 pairs of opposing leaflets to that specie, while P. discolor presented between 21-26 pairs corroborating that there is plasticity in relation to this characteristic.

The best outcomes in this work about types of recipients for the production of seedlings of $P$. discolor were achieved with plastic bags, however, Pereira and Pereira (1986) report that recipients with big dimensions contribute to the rise of costs of production and of transplanting, even though they give good development to plants. Sturion (1980) informs that the dimensions of recipients bring technical implications and economic ones, being considered the best the one which binds the cost of production and the maximum development of seedlings.

\section{CONCLUSION}

The biometric characteristics of seeds and fruits have diagnostic value to differ the specie inside the genus contributing to the recognition of itself.

Parkia discolor presents epigeous fanerocotiledonar germination. The formation of seedling presents common characteristics of this genus, with coloration and number of foliolums and leaflets to its differentiation. Studies about the anatomy and histochemistry of the specie can help in its comprehension aiming to conservation and economic use.

It is very frequent the incidence of perforated fruit and seeds of $P$. discolor by insects of Coleoptera order in special from Bruchidae family.

For the production of seedlings, the use of plastic bags $\left(900 \mathrm{~cm}^{3}\right)$ despite the use of styrofoam trays with cells $\left(125 \mathrm{~cm}^{3}\right)$ was more appropriate to the development of the plant.

\section{ACKNOWLEGMENTS}

To Foundation for the Support of Research in the State of Amazonas (FAPEAM), for the scholarship given to the first author and for the support on the research; to Alex Bruno dos S. Maciel (in memoriam), Germano Lobo da S. Costa and Carlos Matheus da S. Paixão, for the help in the field collection and for the drawings; to Patrícia Nazário, Elizabeth Rodrigues and Elizabeth Elias, for the support in the Laboratory; 
to Biotupé project and their coordinators, Dr. Edinaldo Nelson dos S. Silva and Dra. Veridiana Scudeller, who collaborated in obtaining the fruits and seeds.

\section{REFERENCES}

Bao F, Baptista de Lima L, Baptista da Luz P. Caracterização morfológica do ramo, sementes e plântulas de Matayba guianensis Aubl. e produção de mudas em diferentes recipientes e substratos. Revista Árvore. 2014;38(1):63-71.

Borror DJ, De-Long DM. Introdução ao estudo dos insetos. Rio de Janeiro: Edgard Blucher; 1969. p.192-273.

Brasil. Ministério da Agricultura, Pesca e Abastecimento. Regras para análise de sementes. Brasília, D.F.: Secretaria Nacional de Defesa Agropecuária; 2009. 399p.

Câmara CA, Araújo Neto JC, Ferreira VM, Alves EU, Moura FBP. Caracterização morfométrica de frutos e sementes e efeito da temperatura na germinacão de Parkia pendula (WILLD.) Benth. ex Walp. Ciência Florestal. 2008;18(3):281-90.

Carneiro JGA. Produção e controle de qualidade de mudas florestais. Curitiba: UFPR/FUPEF; Campos: UENF; 1995.

Cavada BS, Madeira SVF, Calvete JJ, Souza LA, Bomfim LR, Dantas AR et al. Purification, Chemical and Imunochemical properties of a new lectin from Mimosoideae (Parkia discolor). Prep Biochem Biotechnol. 2000;30(4):271-80.

Coutinho LM, Struffaldi Y. Observações sobre a germinação das sementes e o crescimento das plântulas de uma leguminosa da mata amazônica de igapó (Parkia auriculata Spruce Mss.).

Phyton. 1971;28(2):149-59.

Damião-Filho CF. Morfologia vegetal. Jaboticabal: FUNEP/UNESP; 1993.

Gomes JP. Caracterização morfológica de plântulas durante a germinação de sementes de Psidium cattleianum e Acca sellowiana (MYRTACEAE). Ciência Florestal. 2015;25(4):1035-41.
Gomes JP, Oliveira LM, Ferreira PI, Batista F. Substratos e temperaturas para teste de germinação em sementes de Myrtaceae. Ciência Florestal. 2016;26(4):285-93.

Gonzaga LM, Silva SS, Campos AS, Ferreira RP, Campos ANR, Cunha ACMCM. Recipientes e substratos para a produção de mudas de jatobá (Hymenaea courbaril L.). Revista Brasileira de Agropecuária Sustentável. 2016;6(1):64-73.

Gurgel ESC, Santos JUM, Bastos MNC, Lucas FCA. Morfologia de plântulas de Leguminosae e o potencial sistemático. Rodriguésia. 2012;63(1):65-73.

Hopkins MJG. Unusual diversities of seed beetles (Coleoptera: Bruchidae) on Parkia (Leguminosae: Mimosoideae) in Brazil. Biological Journal of the Linnean Society. 1983;19:329-38.

Hopkins HCF. Parkia (Leguminosae:

Mimosoideae). 1986. p.74-77. (Monograph 43.

Flora Neotropica)

Hopkins HC, Hopkins MJG. Fruit and seed biology of the neotropical species of Parkia. In.: Sutton SL, Whitmore TC, Chadwick AC. Tropical rain forest: ecology and management. Blacwell scientific publications. Oxford: 1983. p.197-209.

Ibarra-Manríquez G, Martinez-Ramos M, Oyama K. Eedling functional types in a lowland rain forest in Mexico. American Journal of Botany. 2001;88(10):1801-12.

Iganci JRV. Parkia in Lista de Espécies da Flora do Brasil. Jardim Botânico do Rio de Janeiro. [acesso em: 20 mar 2015]. Disponível em: http:// floradobrasil.jbrj.gov.br/jabot/floradobrasil/ FB23107.

Melo MGG. Frutos, sementes e desenvolvimento plantular de três espécies de Parkia $\mathrm{R}$. Br. (Fabaceae-Mimosoideae): uma abordagem morfoanatômica, histoquímica e tecnológica [tese]. Manaus: Universidade Federal do Amazonas; 2011.

Melo MGG, Mendonca MS, Nazario P, Mendes AMS. Superação de dormência em sementes de

Revista Árvore. 2017;41(2):e410206

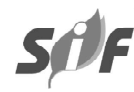


três espécies de Parkia spp. Revista Brasileira de Sementes. 2011;33(3):533-42.

Moreira FMS, Moreira FW. Características da germinação de sementes de 64 espécies de leguminosas florestais nativas da Amazônia, em condições de viveiro. Acta Amazonica. 1996;26:3-16.

Pereira AV, Pereira EBC. Influência do tamanho do saco plástico no desenvolvimento de mudas de seringueira. Pesquisa Agropecuária Brasileira. 1986;21(9):945-8.

Pereira AS, Ferreira SAN. Superação da dormência em sementes de visgueiro-do-igapó (Parkia discolor). Acta Amazonica. 2010;40(1):151-6.

Ribeiro JELS, Hopkins MJG, Vicentini A, Sothers AS, Costa MAS, Brito JM et al. Flora da Reserva Ducke: guia de identificação das plantas vasculares de uma floresta de terra - firme na Amazônia Central. Manaus: INPA/DFID. -AM; 1999.

Rocha CRM, Costa DSC, Novembre ADdaLC, Cruz ED. Morfobiometria e germinação de sementes de Parkia multijuga Benth. (Fabaceae-Mimosoideae). Nativa. 2014;2(1):42-7.

Rodrigues RS, Feitoza GV, Flores AS. Taxonomic relevance of seed and seedling morphology in two Amazonian species of Entada (Leguminosae). Acta Amazonica. 2014;44(1):19-24.

Santana DG, Pereira VJ, Brandão NAL, Lobo
GA, Martins MC. Intensidade da dormência de sementes de Parkia pendula (Willd.) Benth. ex Walp. (Fabaceae). Interciencia. 2015;40(10):71015.

Santos HHD, Matos VP, Albuquerque APC, Sena LHM, Ferreira EGBS. Morfologia de frutos, sementes e plântulas de Averrhoa bilimbi L. oriundas de dois estágios de maturação. Ciência Rural. 2014;44(11):1995-2002.

Silva AL, Dias DCFS, Lima LB, Morais GA. Methods for overcoming seed dormancy in Ormosia arborea seeds, characterization and harvest time. Journal of Seed Science. 2014a;36(3):318-25.

Silva JRO, Albuquerque MCF, Silva ICO. Armazenamento de sementes de Parkia pendula (Willd.) Benth. ex Walp. (FABACEAE) em diferentes embalagens e ambientes. Floresta e Ambiente. 2014b;21(4):457-67.

Souza LAG, Silva MF. Bioeconomical potential of Leguminosae from the Lower Negro River, Amazon, Brazil. Lvonia. 2003;5(1):15-24.

Sturion JA. Influência do recipiente e do método de semeadura na formação de mudas de Schizolobium parahyba (Vellozo) Blake - fase de viveiro. Boletim de Pesquisa Florestal. 1980;1:89-100.

Teixeira CAD. Interação insetos-sementes: O mutualismo é possível. Porto Velho: Embrapa Rondônia; 2005. 15p. 